\title{
GENERATION Z ENTERS INTO THE LATVIAN BUSINESS ENVIRONMENT
}

\author{
Irena Silinevica ${ }^{1}$, Laila Meirule ${ }^{2}$ \\ ${ }^{1}$ Dr.sc.ing., professor, Rezekne Academy of Technologies, Rezekne, Latvia \\ e-mail: irena.silinevica@rta.lv \\ 2 Student of Master study programme "Information systems of electronic \\ commerce" Rezekne Academy of Technologies, Rezekne, Latvia, \\ e-mail: meirule.laila@gmail.com
}

\begin{abstract}
There are five different generations in the Latvian labour market. Each generation has its own values and life experience. Recent research has shown that generation $Z$ entering the labour market is significantly different from previous generations. They have different approaches when it comes to purchasing, choosing a career, working attitude, and so on. Therefore, research is needed to understand what changes this generation will bring to the business environment in the years to come. The aim of this research study is to investigate some of the different aspects of generation $Z$ behaviour in the labour market. This research study includes theoretical and empirical parts. Findings of various theoretical studies on distinctive values and attitudes of generation $Z$ have been investigated. The empirical study compares the values of different generations and highlights the differences between the generations in the labour market. Recommendations are made for successful integration of generation $Z$ into the business environment.
\end{abstract}

Keywords: Z generation, labour force.

JEL Code: J82.

\section{Introduction}

There are five different generations (the Veterans, the Baby-boomers, generation $X$, generation $Y$, and generation $Z$ ) are working in the labour market of Latvia. In 2018, 909.4 thousand or $64.5 \%$ of the population aged 15 to 74 were employed in Latvia, according to the results of the Labour Force Survey of the Central Statistical Bureau (CSB). In this research study, the definition of generation is used from a Dictionary of Sociology: "Generation is a form of an age group whose members were born around the same time, as a group of individuals who were born, matured and are living in the same historical period" (Scott et al., 2005). The youngest generation $Z$ was born after 2000 . That means the majority of this generation is still under the age of 18, and most of them are not yet allowed to vote. Most of generation $Z$ are students, but a significant part of this generation have already entered the labour market. Each generation comes with its own values and perspective of the world based on their lifetime experiences. These differences give each generation unique work values and work ethics and preferred ways of managing and being managed. Many scientists, who analyse attitudes of different generations, notice that they have different 
points of view towards relationship with managers, due to which different motivational tools and communication methods need to be applied to them.

In the coming years, Veterans will leave the active labour market in Latvia. Four generations will remain in the Latvian labour market: Babyboomers, generation $X$, generation $Y$, and generation $Z$. The current generation $\mathrm{Z}$ will play the important role in the labour market around the world for the next 40 years. Generation $Z$ enters the business environment as employers, employees, and consumers. Development of a country largely depends on the current generation $Z$ and its self-realization. Generation $Z$ differs from the other generations, and its behaviour in the labour market has been explored insufficiently around the world and also in Latvia. Therefore, researching the self- actualization of generation $Z$ and studying possible differences with the other generations in this issue is very important for management of social and economics processes.

The aim of this research study is to investigate some of the different aspects of generation $Z$ behaviour in the labour market.

To achieve this aim, several tasks were defined:

- to give insight into some theoretical findings about behaviour of generation $Z$ in the social and business area;

- $\quad$ to conduct a pilot survey about the attitude of different generations towards their career development and to investigate the values of various factors for generation $Z$;

- $\quad$ to analyse the results of the survey;

- to develop conclusions and recommendations.

Object of the study: the generations in the labour market.

Subject of study: values of generation $Z$.

Research hypothesis. The self-actualization traits are different for different generations in the labour market. Therefore, social and economic management processes must take this into account.

Novelty: The self-actualization factors of generation $Z$ are analysed. The proposed recommendations could be used for including generation $Z$ in the labour market, taking into account the differences of this generation.

To achieve the objectives of this research study, the following research methods were used: content analysis, SPSS, comparative analysis, synthesis, abstract and logical construction methods for examining several values of different generations. 


\section{Research results}

\section{Insight into some theoretical findings relating to different generations in the labour market}

The research (7 Unique Characteristics..., 2018) published by Oxford Summer School noted that "generation $\mathrm{Z}$ is distinctive, different and not to be ignored... They have grown up with the knowledge that they can speak to anyone around the world at a moment's notice, and through assorted social media networks, that is what they have been doing for their entire lives...For this generation, electronics that were a luxury to their parents and older siblings have always been a necessity for living in the modern world. This facility with technology has sometimes between used to describe the entire generation; besides, they have also been called neo-digital natives. Generation $\mathrm{Z}$ is the first generation for whom the extraordinary technological advances of the last 20th century are just a normal part of life...They dream of becoming entrepreneurs, building up their own businesses and never needing to answer to a boss. With all the resources of the Internet at their disposal, they know that running your own business can be very hard work, but they are ready for it because they see it as a route to the financial security that they prioritise". The following unique features of generation $Z$ were defined in the above noted article: 1) they are digital natives; 2) the world they live in has never felt safe; 3) they are accepting things; 4) they are health-conscious; 5) they value their privacy; 6) they are entrepreneurial and worried about their future prospects; 7) they are changing the distinction between childhood and adulthood.

A survey-based study (Francis, et al., 2018) carried out in Brazil found that generation $Z$ behaviour is based on a search for truth that values individual expression and avoids labels. They mobilize for a variety of reasons. They are convinced of the effectiveness of dialogue in resolving conflicts and improving the world. They make decisions and deal with institutions in a very analytical and pragmatic way. They are true digital natives: from the earliest youth, they have been exposed to the Internet, to social networks, and to mobile systems. That context has produced a hypercognitive generation being very comfortable with collecting and crossreferencing many sources of information and with integrating virtual and offline experiences. The authors of the research study concluded that generation $Z$ behaviour creates a new concept of consumption: consumption as access rather than property, consumption as an expression of an individual's identity, and consumption for ethical reasons. Thereby companies need to rethink how they deliver value to the consumer, balance scale and mass production versus personalization, and - more than ever - 
practice what they preach in marketing and work ethics. For generation $Z$ (Francis, et al., 2018), the main spur to consumption is the search for truth, in both a personal and a communal form. This generation feels comfortable not having only one way to be itself. Its search for authenticity generates greater freedom of expression and greater openness to understanding different kinds of people. Generation $Z$ faith in dialogue combines a high value for individual identity, the rejection of stereotypes, and a considerable degree of pragmatism. This generation of self-learners is also more comfortable absorbing knowledge online than in traditional institutions of learning. Consumption has also gained a new meaning. For generation $Z$, consumption means having access to products or services, not necessarily owning them. As access becomes the new form of consumption, unlimited access to goods and services (such as car-riding services, video streaming, and subscriptions) creates value. Products become services, and services connect consumers (Francis, et al., 2018).

A research study by Valickas and Jakštaite (Valickas et al., 2017) introduces the results of empirical study that explain the causes determining differing attitudes of the representatives of different generations. The data of the research indicates that different generations in Lithuanian organizations are significantly different in self-assigned personal characteristics, evaluations of optimal length of employment relations with one organization, motivating factors in the organizational environment and preferred leadership.

The staff writer \& editor at TTI Success Insights, Dave Clark, affirmed that generation $Z$ is a very different and unique group compared with its Millennial counterparts. He came to the following conclusions (Clark, 2019).

- Generation $Z$ is financially focused.

- Generation $Z$ is entrepreneurial. Generation $Z$ is competitive.

- Generation $Z$ is all about technology. From the time of their birth, the Internet and cell phones mostly were commonplace. Generation $Z$ wants instant gratification, and they know if they need information, it is easily accessible.

- Generation $Z$ enjoys other people. Generation $Z$ wants to be heard.

- Change is welcomed by generation $Z$. Unlike previous generations, this group is actively engaged in political conversations despite many of them not yet be able to vote. Information is easier to find, making them "experts" on subjects very quickly. With this mentality, they tend to rally behind causes that resonate with them, often before they even take time to consider the "other side."

- Diversity does not even register with generation $Z$. They have grown up in a diverse world and it is all they know. Neither race, sexual orientation nor religion are the identifying characteristics 
that they may have been for previous generations. People are just people to generation $Z$. It does not mean they will not judge, however. Generation $Z$ is more likely to judge someone for what you are, rather than for who you are.

- Generation $Z$ prefers independence. Millennials are all about collaboration, but the competitive nature of generation $Z$ contributes to them wanting to control their own destiny and not rely on others for their own success.

- $\quad$ Generation $Z$ has strong opinions and wants them to be heard. This is especially true in the workplace, where they expect to be an equal contributor.

- $\quad$ Generation $Z$ can be a lot like their parents.

- Focus group of one.

Skyller Jolley (Skyller, 2019) focused his research on how generation $Z$ traits change the way they learn and discover knowledge. He gave insight in the key characteristics that define generation $Z$. They are as follows.

1. Generation $Z$ are technologically advanced and knew how to use a smartphone from an early age.

2. Generation $Z$ representatives have never seen the world without the Internet and thus have affinity for texting and messaging on mobile apps or online platforms.

3. Generation $Z$ absorbs tons of new information every day.

4. Generation $Z$ perceives information visually.

5. Being independent, generation $Z$ is self confident and autonomous.

6. Generation $Z$ representatives have short attention spans and are less focused than their predecessors. The attention span of generation $Z$ is only 8 seconds, so one should try hard to capture and hold their attention.

7. Generation $Z$ are environmentally aware. They value the ecofriendly and healthy lifestyle much more than any previous generation. Maybe this generation will actually have a positive impact on the environment?

8. Multitasking is also one of the positive generation $Z$ traits. Due to their extraordinary ability to process and absorb lots of information within seconds, generation $Z$ kids can easily handle several tasks at once.

JKCP (Julian Krinsky camps \& programs) summer programmes are adapted for generation $Z$ traits in relation to learning. At one of the JKCP summer camps, students can learn how to make money as a video blogger by participating in the YouTube Influencer class. The experienced instructors 
teach students on how to become successful digital entrepreneurs with the help of YouTube videos (Skyller, 2019).

A Unique Enrichment Programme, offered at JKCP, is tailored specifically to the life rhythm of generation $Z$. This programme allows the students to study at their own pace as well as choose what they want to study, how deep they want to study this subject, and when they want to do it (Skyller, 2019).

Matt Kleinschmit researched generation $Z$ from a consumer perspective. Using an infographic, he has worked out 10 valuable advices that every marketer should consider before trying to sell something to generation $Z$. He noted that generation $Z$ is starting to enter the workforce and earning their own income. The main findings of his research was that generation $Z$ "is a generation of CCs (Culture Creators) that are redefining entertainment, consumption, the workplace and marketing. The CCs are empowered, connected, empathetic self-starters that want to stand out and make a difference in the world. They have created a new Cultural Currency that values uniqueness, authenticity, creativity, shareability and recognition. What is different for this generation is not as simple as the Internet or technology. Technology is an important component, but what has changed is this generation's relationship with culture". Matt Kleinschmit underlined "the need to engage with and understand generation $Z$ - an increasingly important group of customers who will help to shape the future. As generation $Z$ enters the workforce and its purchasing power increases, companies cannot afford to act within conventional assumptions or generational frameworks. A deeper understanding of generation $Z$ customers, one that is rooted in continuous, two-way dialogue, is required to deliver products, services, and experiences that this elusive and evolving generation is looking for" (Kleinschmit, 2019).

Generation $Z$ consumers differ from previous generations. Therefore, it is important for marketers to understand these differences. Entrepreneurs should be interested in learning how to properly sell a product or service to generation $Z$ consumers. Several scientists studied this phenomenon. For example, using infographics, 10 marketing tips for generation $Z$ were worked out (10 Marketing Tips..., 2015). They are as follows.

Tip 1: The most important thing is to take them seriously. They are not just teenagers - they are consumers. Generation $Z$ teens have access to serious cash.

Tip 2: Understand the user persona. They are go-getters, activists, and dream big. $75 \%$ of teens want to convert hobbies to full time jobs. $72 \%$ of high school students want to start a business someday and $61 \%$ would rather be an entrepreneur than an employee when they graduate college. 
Tip 3: Identify correct social platforms with market research before you begin promoting and marketing your product. Generation $Z$ prefer Snapchat \& Instagram. Facebook, Twitter \& LinkedIn are less important.

Tip 4: Mobile marketing should be the primary platform. Generation $Z$ teens receive over 3000 text messages a month. They watch $2 \mathrm{x}$ as many videos on the mobile as any other demographic. $70 \%$ watch 2 hours of YouTube per day.

Tip 5: Produce a video. Even something small. Especially on the mobile: YouTube, e.t.c.

Tip 6: Your product pitch should be brief and to the point. Generation $Z$ has an attention span of 8 seconds.

Tip 7: Your campaign can be edgy and should be progressive. But do not be trashy. $88 \%$ say that they are exploring their sexuality more than in the past. However, drug use, alcohol consumption, smoking, and teenage pregnancy is at their lowest levels for decades.

Tip 8: Develop unique products \& campaigns and provide visual depth. Generation $Z$ shuns conformity and tradition. They like storytelling and visual displays.

Tip 9: Do not be too local or provincial. Go global, in terms of both locales and backgrounds. Generation $Z$ has global aspirations, and draws inspiration from all over the world.

Tip 10: Promote an uplifting and positive message - ideally your product can make the world a better place. $60 \%$ want to change the world, compared with just $39 \%$ of millennials.

Findings of the above-mentioned studies confirmed, that generation $Z$ differs from previous generations in terms of behaviour, information perception, and values. They have high self-confidence, high digital technology skills, they are easy to navigate in the information environment of the digital environment, and they are independent because of many of them work and study at the same time. They need a different approach to learning. They are different from other generations of consumers, they have different values.

\section{Empirical study}

The aim of the empirical study is to compare the attitude of different generations towards their career development and to investigate the values of various factors for generation $Z$.

To achieve this aim, a survey of different generations' groups was carried out. 200 questionnaires (electronically) were distributed. The largest survey group was generation $Z-115$ respondents. The respondents of generation $Z$ were students born after 2000 , and they have already entered 
the labour market. Given the small number of respondents to this survey, this empirical study could be seen as a pilot survey.

Respondents were selected from the following target groups: Babyboomers, generation $X$, generation $Y$, and generation $Z$. Relative units percentage - are used for the analysis, taking into account the different number of respondents in the selected different generational groups. A percentage is calculated for each group separately, based on the total number of respondents in each group. Study period: December 2018 - March 2019.

The following research methods were used: SPSS, comparative analysis, synthesis, abstract and logical construction methods for studying several values of different generations and working out conclusions and recommendations.

\section{Empirical study results}

The data (Table 1) show the attitudes of different generations towards the following factors in their career development: willingness to pursue a career, willingness to take responsibility, readiness to take the lead, readiness to engage in politics, attitude towards further education.

Table 1 The attitude of different generations towards their career development (Source: compiled by the authors)

\begin{tabular}{|l|c|c|c|c|c|c|}
\hline $\begin{array}{c}\text { Genera- } \\
\text { tion }\end{array}$ & $\begin{array}{c}\text { Willing- } \\
\text { ness to } \\
\text { develop } \\
\text { one's } \\
\text { career, } \\
\%\end{array}$ & $\begin{array}{c}\text { Readiness } \\
\text { to take res- } \\
\text { ponsibi- } \\
\text { lities, } \\
\%\end{array}$ & $\begin{array}{c}\text { Readi- } \\
\text { ness to } \\
\text { take the } \\
\text { lead, } \\
\%\end{array}$ & $\begin{array}{c}\text { Willingness } \\
\text { to defend } \\
\text { one's } \\
\text { opinion, } \\
\%\end{array}$ & $\begin{array}{c}\text { Readiness } \\
\text { to engage } \\
\text { in } \\
\text { politics, } \\
\%\end{array}$ & $\begin{array}{c}\text { Positive atti- } \\
\text { tude to } \\
\text { further } \\
\text { education, } \\
\%\end{array}$ \\
\hline Baby- & 75 & 63 & 69 & 69 & 69 & 94 \\
boomer & 100 & 76 & 76 & 71 & 82 & 94 \\
X & 84 & 81 & 84 & 81 & 84 & 97 \\
Y & 91 & 83 & 88 & 76 & 86 & 88 \\
Z & & & & & & \\
\hline
\end{tabular}

According to the data of the survey, all the generations are ready to continue their education (Table 1). The data of this table show that generation $\mathrm{Z}$ in comparison with the other generations has the highest rate for readiness to take responsibility, readiness to take the lead, willingness to defend their opinion, and readiness to engage in politics. $88 \%$ of the 
respondents of generation $Z$ showed willingness to take the lead, $83 \%$ of the generation $Z$ respondents indicated their willingness to take responsibility, $76 \%$ of the generation $Z$ respondents showed their willingness to defend their opinion, and $86 \%$ of the generation $Z$ respondents indicated their willingness to engage in politics. The willingness to defend personal opinion $(76 \%)$ is expressed by fewer generation $Z$ respondents than the willingness to engage in politics (86\%). The free expression and defence of personal opinion is the basis of a free democratic society. Neither a politician nor a leader is inconceivable without the ability to express and defend their views. Comparing the data (Table 1), it can be concluded that the respondents who are ready to engage in politics are not always ready to defend their personal opinion. This means that generation $Z$ must be oriented towards the free expression of personal opinion. Considering that human development is hindered even if one does not know or is afraid to defend his/her opinion, attention should be paid to this issue. It could be developed both in formal education and in various training activities.

Table 2 shows the main values of generation $Z$ that were determined by the respondents. To some extent, these values reveal the self-realization directions of generation $Z$.

Table 2 Values of various factors for generation $Z$ born after 2000

(Source: compiled by the authors)

\begin{tabular}{|l|l|l|l|}
\hline \multicolumn{1}{|c|}{ Factors } & $\begin{array}{c}\text { Very important, } \\
\%\end{array}$ & Moderate, $\%$ & Irrelevant, \% \\
\hline Self- realization & 75 & 25 & 0 \\
\hline Power & 7 & 52 & 41 \\
\hline Wealth & 21 & 70 & 9 \\
\hline Achievements & 84 & 15 & 1 \\
\hline Courage & 60 & 37 & 3 \\
\hline The state & 32 & 59 & 9 \\
\hline Work & 65 & 34 & 1 \\
\hline Respect for traditions & 39 & 48 & 13 \\
\hline Identity & 74 & 25 & 1 \\
\hline Respect for colleagues & 38 & 69 & 8 \\
\hline Safety & 60 & 38 & 2 \\
\hline
\end{tabular}

According to the data (Table 2), achievements (84\%) and selfrealization (75\%) are the most important for the generation $\mathrm{Z}$ group. Power is not too attractive, just $7 \%$ of the respondents noted this factor as very important and $41 \%$ respondents noted this factor as non-relevant. Wealth is very important for only $21 \%$ of the respondents, and for the most respondents $(70 \%)$ the country factor was moderately important. Identity awareness and national awareness are powerful motivators. Generation Z 
awareness of their identity is high. The attitude towards the state is less positive. Only $32 \%$ of the respondents regard the country as a significant value, while $9 \%$ consider it a low value. If the state as a body guaranteeing civil liberties does not have enough value, it means that one does not understand what the state means or does not see his/her place in it.

\section{Conclusions and suggestions}

Generation $Z$ enters the labour market as employers, employees, and consumers. According to theoretical investigations, generation $Z$ perceives information differently and acquires knowledge differently, and they have low levels of attention retention. Several educational institutions are trying to adapt their teaching methodologies to the training of these students by introducing a digital approach.

The results of this empirical pilot study confirm that generation $Z$ is different from previous generations. Under the influence of globalization and information technology, they have been accustomed to using the Internet and social networks since childhood, and the majority of this generation combine training with work. They are ambitious and most of them want to become employers. The results of this pilot study confirm that they have high self-actualization, achievements are important for them, power is not too attractive, wealth is very important for only $21 \%$ of the respondents, and for the most respondents $(70 \%)$ the country factor was moderately important. Identity awareness and national awareness are powerful motivators. Generation Z people awareness of their identity is high. The attitude towards the state is less positive. Only a third of the respondents regard the country as a significant asset.

Generation $Z$ does not always feel attached to their country and sometimes does not see their place in it. This means that the migration problems in Latvia will remain relevant. In this regard, school and universities in their training programmes should pay more attention to the importance of statehood, the love of the motherland and patriotism. It is very important to develop students' abilities to express their opinions in a meaningful way and to defend them in public. For this purpose, the ability to defend one's opinion must be included in the curriculum as a necessary competence.

Generation $Z$ people are different from other generations of consumers, they have different values. Generation $Z$ has a new approach to consumption. The researchers in Latvia should focus more on investigating these issues and developing concrete proposals that could be implemented in student training programmes, as well as developing specific proposals to help marketers work with generation $Z$ consumers. 
There is a need for a public debate on generation $Z$ differences, involving parents, teachers, employers and social organizations. The purpose of these discussions would be to understand and accept the differences between the generations. This would help to accept changes in the social and working environment. Extensive research needs to be done in Latvia, involving as many generation $Z$ people as possible.

A question for discussion: Could prolonged use of smart devices affect the functioning of the human brain's right and left hemispheres? Could this not explain the behavioural differences of generation $Z$ ?

\section{References}

1. Clark, D. (2019). 10 Defining Characteristics of Generation Z. Retrieved from https://blog.ttisuccessinsights.com/10-defining-characteristics-of-generation-z

2. Hoefel, F. (2018.). Unique characteristics of Generation Z. Retrieved from https://www.oxford-royale.co.uk/articles/7-unique-characteristics-generationz.html

3. Kleinschmit, M. (2019). Generation Z Characteristics: 5 Infographics on the Gen $Z$ Lifestyle. Retrieved from https://www.visioncritical.com/blog/ generation-z-infographics:

4. Nodarbinātība 2018. gadā. Retrieved from https://www.csb.gov.lv/lv/statistika/ statistikas-temas/socialie-procesi/nodarbinatiba/meklet-tema/2582nodarbinatiba-2018-gada

5. Scott, J., Marshall, G. (2005). A Dictionary of Sociology. Oxford University Press

6. Skyller, J. (2019.). Generation $z$ characteristics \& traits that explain the way they learn. Retrieved from https://info.jkcp.com/blog/generation-z-characteristics

7. Tanner, R. (2019). Understanding and Managing the 4 Generations in the Workplace. Retrieved from https://managementisajourney.com/understandingand-managing-the-4-generations-in-the-workplace

8. 'True Gen': Generation $Z$ and its implications for companies. Retrieved from https://www.mckinsey. com industries/consumer-packaged-goods/ourinsights/true-gen-generation-z-and-its-implications-for-companies

9. Valickas, A., Jakštaite, K. (2017). Different generations' attitudes towards work and management in the business organizations. Retrieved from https://www.researchgate.net/publication/323014394_different_generations'_ attitudes_towards_work_and_management_in_the_business_organizations

10. 10 tips for Marketing towards Generation Z. (2015). Branding, Strategy, Trends, UFA Polls Surveys. Retrieved from http://upfrontanalytics.com/marketinggeneration-z-infographic/ 